\title{
FOREST PEDAGOGICS POTENTIAL IN PRIMARY EDUCATION
}

\section{[POTENCIAL LESNEJ PEDAGOGIKY V PRIMARNOM VZDELAVANI]}

\section{Dana Kollarova}

doi: 10.18355/PG.2018.7.1.15

\begin{abstract}
Forest pedagogics as a part of the environmental education is the teaching of the forest ecosystem and human being's education to a long-term sustainable way of life. With reference to the ISCED 1 educational programme, the area of Human being and nature include the themes the teaching of which may become more effective by the change of educational environment, e. g. teaching about forest realized in a forest with active participation of a specialist - a forest pedagogue. The paper involves the teachers' experiences in the forest pedagogics and its share in natural science literacy development of students in primary schools.
\end{abstract}

\section{Key words}

forest pedagogics, forest pedagogue, natural science literacy, Prvouka (i. e. first-year primary school subject in basic natural science), natural science, effectiveness standards

\section{Anotácia}

Lesná pedagogika ako súčast' environmentálnej výchovy je učenie o lesnom ekosystéme a výchove človeka k dlhodobo udržatel'nému spôsobu života. Vychádzajúc z obsahu vzdelávacieho programu ISCED 1 sú v oblasti Človek a príroda témy, ktorých vyučovanie sa môže ukázat' ako efektívne zmenou edukačného priestoru, napríklad učenie o lese v lese, a to za aktívnej účasti odborníka - lesného pedagóga. Príspevok prináša skúsenosti učitel'ov s lesnou pedagogikou a jej podiel na rozvíjaní prírodovednej gramotnosti žiakov primárneho stupňa vzdelávania.

\section{Kl’účové slová}

lesná pedagogika, lesný pedagóg, prírodovedná gramotnost', prvouka, prírodoveda, výkonové štandardy

\section{Úvod}

Les a lesné prostredie sa môže stat' pre školské podmienky vo formálnom aj neformálnom vzdelávaní vhodným prostriedkom pre nadobúdanie vedomostí a súčasne pre utváranie hodnotového systému. Výhodu lesného prostredia treba vidiet' $\mathrm{v}$ tom, že je akousi každoročne obnovujúcou sa učebnicou prírody. Tá umožňuje žiakom nielen utvárat' si vzt'ah k prírodnému prostrediu a najbližšiemu environmentu, ale zároveň priamym kontaktom cez pozorovanie, skúmanie stimulujeme u nich prírodovednú gramotnost' a podporujeme ich reálny pohl'ad na svet. Čo je v súčasnosti dôležité, že cez 
kontakt s lesným prostredím podnecujeme prirodzený pohyb detí, ich pozorovacie schopnosti, podnecujeme ich záujem, rozvíjanie poznania o prírode a utvárania citlivého vzt’ahu $\mathrm{k}$ všetkému živému, $\mathrm{k}$ pochopeniu harmónie prírody, ale aj pochopeniu významu lesov v prírode a pre človeka. Takýto prístup môže viest' k ekologickému mysleniu aj konaniu.

Základným predpokladom toho, aby sme u žiakov/detí mohli týmto spôsobom smerovat' k uvedeným ciel'om je, že ich s lesom oboznámi nielen odborník - lesník, resp. lesný pedagóg, ale že les sa stane našim edukačným priestorom. Princíp lesnej pedagogiky spočíva v tom, že žiaci sa učia o lese v lese, prostredníctvom vyškoleného profesionála z lesníckeho sektoru lesného pedagóga. Ciel’om nášho príspevku je predstavit’ niektoré skúsenosti s lesnou pedagogikou, pri jej systematickom využívaní vo vzdelávacej oblasti Človek a príroda.

\section{Teoretický koncept lesnej pedagogiky}

Používaný pojem lesná pedagogika vychádza z európskeho konceptu a základných dokumentov vypracovaných Pracovnou skupinou Forest Communication Network (FCN) a Medzinárodnou siet’ou lesných pedagógov. Lesnú pedagogiku tiež môžeme vnímat' ako „pedagogické hnutie“, ktoré vychádza z pedagogiky vol'ného času, a to prevažne $\mathrm{v}$ nemecky hovoriacich krajinách.

Ak by sme nazreli do histórie, idea lesnej pedagogiky vznikla v 19. storočí v Amerike. Jej zakladatel'om bol Joseph Cornell z Kalifornie. Jeho publikácie k predmetnej problematike mali ohlas najmä v USA, neskôr jeho metodiku nemecky hovoriace štáty Európy (Švajčiarsko, Rakúsko, Nemecko). V roku 2004 bola vo Viedni založená Siet európskych pedagógov - Wald Paedagogik Netzwerk.

Španielska psychologička H. Freire na Medzinárodnom kongrese lesných pedagógov 2013 v Bilbao vo svojej prednáške Zelená pedagogika 21. storočia prezentovala výsledky výskumu, ktorým zist'ovala aký je životný štýl detí a mládeže. Upozornila na to, že technologické výdobytky doby det’om im do istej miery znemožňujú dotýkat' sa okolitého sveta prírody. Det’om chýba kontakt so živými tvormi, rastlinami, organizmami. Uviedla, že výsledkom toho môžu byt' aj alergie, obezita, rôzne závislostí, agresivita, depresie, problémy s pozornost'ou a pod. Tiež zistila, že sa objavuje nový fenomén - „biofóbia“, strach zo živého, kde sa človek bojí chytat živých tvorov. Deti sú často príliš chránené zo strany rodičov - „overprotected“, čím ich ochudobňujú o podnety z okolitého prostredia. Zdôraznila, že súžitie s prírodou nie je len o vedomostiach, ale najmä o citovom prežívaní (bližšie, Kollarova - Marusakova, 2015).

Je aj vedecky dokázané, že pobyt $\mathrm{v}$ lese posilňuje zdravie človeka. Zvlášt' deti, sa po návšteve lesa cítia uvol’nene. Pobyt v lesnom prostredí tlmí sympatický nervový systém, zatial' čo sa aktivuje parasympatický nervový systém, ktorý je zodpovedný za navodenie stavu pokoja a spomalenie. Čo sa týka schopnosti učit' sa a rozvíjat' sa $\mathrm{v}$ lesnom prostredí, les podporuje kreativitu a zodpovednost', upozorňujú na to Renz-Polster, Huther (2013), ale tiež aj rozvoj motoriky, redukuje stres, mentálnu únavu a obnovuje pozornost', 
rozvíja aktívny životný štýl, povzbudzuje detí podstúpit' riziko (bližšie Marusakova, 2010).

O koncepcii lesnej pedagogiky môžu hovorit’ tie krajiny, ktoré majú lesy, teda vhodné prírodné podmienky. Slovensko je z tohto pohl'adu prekrásnou a vyhovujúcou krajinou, ktoré otvára možnosti vstúpit’ lesnej pedagogike do pedagogického priestoru, a to $\mathrm{v}$ aplikačnej, ale aj výskumnej rovine a dovolíme si tvrdit', že na všetkých stupňoch vzdelávania.

\section{Podmienky lesnej pedagogiky na Slovensku}

Na Slovensku sa lesná pedagogika rozvíja vd’aka L’udmili Marušákovej, jej prednáškami, publikáciám, ale aj myšlienke dat' akreditovat' vzdelávací program lesná pedagogika pre lesníkov. L'. Marušáková pôsobila do roku 2015 vo Zvolene v Národnom lesníckom centre a v súčasnosti pôsobí v zahraničí, v Európskej sieti lesných pedagógov. Od roku 2013 máme možnost' s n̆ou spolupracovat' práve v oblasti vzdelávania lesných pedagógov. V súčasnosti vychádza na Slovensku v Národnom lesníckom centre prvá študijná príručka pre lesných pedagógov a pre učitel'ov Lesná pedagogika (bližšie Loyova, D. ed, 2018).

Marusakova (2010) vidí základ lesnej pedagogiky v týchto pilieroch - vo vyvolaní zážitku, v prežívaní a jeho spracovaní, pričom práve lesné prostredie a aktívna účast' lesného pedagóga robí zážitok hodnotným. Len dodáme, že hodnotným aj z hl'adiska rozvíjania kognitívnych funkcií. Perspektívy lesnej pedagogiky môžeme vidiet' v tom, že stimulujeme ňou u žiakov aj environmentálne vzdelávanie, tým, že doplńame poznatky a skúsenosti o životnom prostredí, tiež rozvíjame ich zmyslové vnímanie (vnímanie mimoumeleckých prostriedkov - šumenie lesa, zvuky zvierat a spev vtákov). Tým žiakov vedieme $\mathrm{k}$ aj ohrane a tvorbe trvalo udržatel'ného rozvoja.

Na Slovensku bola vypracovaná Koncepcia lesnej pedagogiky ako súčasti environmentálnej výchovy (Marusakova, et al., 2010). Bola schválená vedením Ministerstva pôdohospodárstva a rozvoja vidieka č.2824/2011-710, v rámci nej bola vytvorená nasledujúca definícia: „Lesná pedagogika ako súčast' environmentálnej výchovy, je učenie o lesnom ekosystéme a výchove človeka $k$ dlhodobo udržatel’nému spôsobu života na príklade fungovania lesných ekosystémov. Aktivity lesnej pedagogiky zabezpečujú certifikovaní lesní pedagógovia a je určená všetkým ciel'ovým skupinám, najmä detom a mládeži. Využiva aktivizujúce metódy a formy zážitkového učenia a projektového vyučovania. Poskytuje nielen vedomosti, ale oslovuje aj emocionálnu stránku človeka, podporuje získavanie zručností aj celostný rozvoj osobnosti“.

Existujú už aj na Slovensku parciálne skúsenosti lesných pedagógov so školami, ktoré však nemáme jednoznačne uchopené v pedagogickodidaktickej ani teoretickej rovine, hoci skúsenosti učitel'ov ukazujú, že lesná pedagogika má svoje opodstatnenie vo vyučovacom procese.

\section{Lesná pedagogika vo formálnom vzdelávaní}

Ciele lesnej pedagogiky majú priesečníky s prírodovedným vzdelávaním aj na primárnom stupni. Ak sa pozrieme na charakteristiku predmetu Prvouka, 
ktorý je zo vzdelávacej oblasti Človek a príroda, vyučuje sa 1. a 2. ročníku ZŠ, tak nájdeme, že ,v prírodovednej oblasti poznávaním organizmov, neživého prostredia a ich vzájomných vzt’ahov oboznamujeme žiakov s reálnym prírodným priestorom prostrednictvom skúmania fungovania vybraných prírodných javov “. Lesnou pedagogikou teda môžeme napĺn̆at’ ciele, resp. výkonové štandardy, ktorými sú okrem iných aj:

- Žiaci si rozvíjajú svoje predstavy o prírodných a spoločenských javoch,

- rozvíjajú si svoje pozorovacie spôsobilosti, aby z bežne zažívaných situácií dokázali získat' nové informácie a obohatit' si doterajšie poznanie,

- $\quad$ sú vedení k porovnávaniu predmetov a javov a k zoskupovaniu,

- rozlišujú vhodné a nevhodné správanie,

- $\quad$ argumentujú podl'a vlastnej skúsenosti, spolupracujú pri jednoduchých skúmatel'ských aktivitách,

- poznajú pravidlá správania sa v rizikových situáciách podl'a vzoru (bližšie www.statpedu.sk).

Vzdelávací štandard prvouky a prírodovedy ako program aktivity žiakov je koncipovaný tak, aby vytváral možnosti na tie kognitívne činnosti žiakov, ktoré operujú s pojmami, akými sú hl'adanie, pátranie, skúmanie, objavovanie, lebo $\mathrm{v}$ nich spočíva základný predpoklad poznávania a porozumenia prírodovedy. $\mathrm{V}$ tomto zmysle nemajú byt' žiaci len pasívnymi aktérmi výučby a konzumentmi hotových poznatkov, ktoré si majú len zapamätat' a následne zreprodukovat'. Práve k tomu môže prispiet' svojimi poznatkami, skúsenost'ami aj lesný pedagóg, vo výučbe v lesnom prostredí.

Ak sa pozrieme na vyššie ročníky, vo vyučovacom predmete Prírodoveda vidíme tiež príležitost' na výučbu lesným pedagógom. Ide o konkrétnejšie výkonové štandardy:

- Rastliny: opísat' funkcie jednotlivých častí rastlín, delit' rastliny na listnaté a ihličnaté, vysvetlit', že plody obsahujú semená;

- Živočíchy: vysvetlit', význam maskovania živočíchov v prírode, vysvetlit' vzt'ah dravec a korist';

- Človek: vysvetlit' závery o funkcii ušnice pri zachytávaní zvuku, poznat' význam zmyslové vnímania (aj ked' sa jedná o oblast' Človek, môžeme to porovnat' so zvieratami žijúcimi v lese);

- Neživá príroda: vysvetlit', aký význam má voda v pôde a ako sa to týka človeka, vediet', že voda sa vyskytuje v rôznych formách.

- Ide len o niektoré výkonové štandardy, ktoré sme spracovali analýzou ŠVP pre primárny stupeň vzdelávania zo vzdelávacej oblasti Človek a príroda, aby sme dokázali opodstatnenost' lesnej pedagogiky v škole (bližšie www.statpedu.sk).

Na primárnom stupni vzdelávania v oblasti formálneho vyučovania môžeme lesnú pedagogiku zaradit' ako súčast' týchto vyučovacích predmetov:

- Prvouka 1. a 2. ročník

- Prírodoveda

- Vlastiveda

3. a 4. ročník

- Etická výchova 1. - 4. ročník (konkrétne oblast' utvárania hodnotového systému a postojov $\mathrm{k}$ sebe, $\mathrm{k}$ iným l’ud'om a k prírode) 
- Výtvarná výchova, Pracovné vyučovanie 1. - 4. ročník (práca s prírodným materiálom, kreslenie, mal'ovanie, modelovanie a podobne). Uvedieme niektoré silné a slabé stránky lesnej pedagogiky v školských podmienkach..

Za silné stránky môžeme považujeme:

- $\quad$ existencia silných lesníckych inštitúcií,

- $\quad$ akreditácia kurzu Lesnej pedagogiky na MŠVVaŠ SR,

- odborné zázemie pre tvorbu, metodiku a koordináciu aktivít lesnej pedagogiky (v súčasnosti máme pomerne silné zázemie v odbornom tíme L. Marušákovej, sú to D. Loyová, A. Melcerová, V. Jaloviarová a d'alší z Národného lesníckeho centra vo Zvolene),

- úspešné projekty, ktoré sa venujú práci s verejnost'ou a so školami (Les ukrytý v knihe),

- $\quad$ informačný systém ( $w w w$.lesnapedagogika.sk, rôzne iné materiály),

- záujem lesníkov o komunikáciu s verejnost’ou a lesnú pedagogiku (dôkazom je to, že si lesní pedagógovia chcú robit' aj nadstavbový modul).

- $\quad$ prezentácia lesníctva prostredníctvom rôznych aktivít, výstavy a pod.

- metodická príručka a v súčasnosti aj spomínaná aktuálna študijná príručka.

Slabé stránky lesnej pedagogiky signalizujú tieto ukazovatele:

- chýba spoločná koncepcia lesnej pedagogiky,

- chýba koordinácia lesnej pedagogiky z úrovne MPRV SR a MŠVVaŠ SR,

- nedostatočná spolupráca lesníckych inštitúcií,

- nedostatočná informovanost' o lesnej pedagogike so samosprávou,

- nedostatok odborno-metodickej literatúry pre učitel'ov,

- chýba systémové riešenie lesnej pedagogiky a financovanie aktivít lesnej pedagogiky,

- nedostatočný status lesnej pedagogiky a lesného pedagóga,

- nedostatok výskumov z oblasti lesnej pedagogiky vo formálnom a neformálnom vzdelávaní,

- $\quad$ slabá informovanost' škôl o možnostiach lesnej pedagogiky pri rozvoji osobnosti žiakov.

\section{Lesný pedagóg}

Lesná pedagogika je riadne akreditovaný program MŠVVaŠ SR, ktorým sa pripravujú lesní pedagógovia pod odborným vedením lektorov, ktorí pôsobia na vysokých školách, alebo metodickom centre. Tieto kurzy sú v rozsahu $80 \mathrm{~h}$. Záujemca o kurz získa potrebné vedomosti a zručnosti z oblastí psychológie, pedagogiky, pedagogickej komunikácie, didaktiky vyučovania, tvorivej dramatiky, projektového a zážitkového vyučovania, práce so širokou verejnost'ou v lesníctve a lesnej komunikácii a práce s l'ud'mi so špeciálnymi potrebami. Vedomosti a zručnosti z uvedených oblastí sú nevyhnutné $\mathrm{k}$ úspešnému ukončeniu kurzu.

Ciel'om kurzu je prostredníctvom poznatkov z vývinovej a pedagogickej psychológie, pedagogiky, didaktiky, prevažne aktivizujúcich metód 
a praktických tréningov zážitkového vyučovania pripravit' účastníkov na plánovanie, realizáciu a vyhodnocovanie programu lesnej pedagogiky vo formálnom vzdelávaní v súlade so ŠVP, jeho obsahovými a výkonovými štandardmi.

V Českej republike je tento predmet povinným vyučovacím predmetom na stredných lesníckych školách. Na stránke www.lesy.cz sa stretneme s touto definíciou lesného pedagóga: Lesný pedagóg je odborník s lesníckym vzdelaním či praxou v lesníctve a úspešný absolvent certifikovaného kurzu lesnej pedagogiky, naplňujúci jej podstatu, vie predstavit’ les zábavnou formou.

Na Slovensku majú lesní pedagógovia stránku, kde môžu komunikovat' so školami, resp. na stránke www.lesnapedagogika.sk si učitelia od predprimárneho stupňa vzdelávania môžu vyhl'adat' svoj región a nájdu v ňom zoznam lesných pedagógov, ktorých môžu oslovit' k výučbe dohodnutej témy. Na uvedenej stránke sa stretneme s touto definíciou lesného pedagóga: Lesný pedagóg je zamestnanec zo štátnych i neštátnych lesníckych inštitúcií, ktorý má lesnícke vzdelanie, praktické skúsenosti z práce v lese a absolvuje špeciálny tréningový program lesnej pedagogiky. Špeciálny tréningovým programom sa rozumie práve spomínané akreditované štúdium. Máme aj takých lesných pedagógov, ktorí si okrem základného modulu A, urobili aj nadstavbové moduly. Zdôrazníme, že ide z ich strany o záujmové vzdelávanie.

\section{Výskum o využívaní lesnej pedagogiky VO Výučbe na primárnom stupni vzdelávania}

V roku 2016 sme uskutočnili v rámci výskumného projektu (Kudelova, Kollarova, 2016) výskum, v ktorom sme riešili výskumný problém: $A k y ́$ je rozdiel $v$ úrovni poznatkov o lese a prírode žiakov 4. ročníka, ktorí absolvovali a tých, ktorí neabsolvovali lesnú pedagogiku? Našim ciel'om bolo teda porovnat' úroveň vedomostí žiakov dvoch tried 4. ročníka, z ktorých jedna absolvovala a jedna neabsolvovala lesnú pedagogiku. Čiastkovým ciel'om bolo zistit', aké subjektívne charakteristiky pripisujú lesnej pedagogike rodičia, učitelia a lesný pedagóg a či vidia v lesnej pedagogike potenciál na rozvoj prírodovednej gramotnosti. Ďalším čiastkovým ciel'om bolo zistit' analýzou úspešnost' v jednotlivých otázkach didaktického testu vlastnej konštrukcie.

Použili sme metódy pološtruktúrované interview, didaktický test. Výskumný súbor nám tvorili dve skupiny - experimentálna a kontrolná. Prvou skupinou - experimentálnou, boli žiaci 4, ročníka ZŠ, ktorí absolvovali aktivity lesnej pedagogiky s lesnou pedagogičkou (D. Loyovou, Národné lesnícke centrum vo Zvolene). Druhou kontrolnou skupinou boli participanti - žiaci, ktorí postupovali v prírodovedných témach tradičnou výučbou, so svojou triednou učitel'kou.

\section{Z výsledkov výskumu}

Upozorníme aspoň na niektoré zistenia, ktoré môžu signalizovat', že má zmysel vo formálnej rovine na primárnom stupni vzdelávania zaoberat' sa 
a zaradit' lesnú pedagogiku do výučby. Učitelia, ktorí žiakov učia, sa vyjadrili aj o týchto hodnotách lesnej pedagogiky:

- Spája žiakov do lepšieho kolektívu;

- Má to prínos pre žiakov aj pre učitel'a, žiaci prijímajú aktivity s radost'ou, nadšením, osvojili si množstvo hier a absolvovali rozmanité pokusy;

- Odborník - lesník je v týchto veciach zbehlejší ako učitel', vie to žiakom lepšie priblížit', podat' aj vlastné zážitky;

- Ukazuje sa, že si učivo lepšie zapamätajú;

- Lesný pedagóg podá žiakom učivo tak, ako by som ja nikdy nedokázal, lebo nie som v tejto oblasti odborníkom.

Vidíme, že učitelia sa nevyjadrujú len k emocionálnej stránke vyučovania, ale uvedomujú si, že má vplyv lesná pedagogika aj na kognitívne procesy.

Z ohlasov žiakom uvedieme, že vyvolalo to u nich radost; ziskali nové poznatky; vyjadrili nadšenie; učili sa vlastnou skúsenost'ou; využivali viaceré zmysly; ocenili, že boli často vonku a rovnako uviedli, že mali z výučby zážitok. Z tvrdení žiakov je pre nás podstatné, že si uvedomujú učenie zapojením viacerých zmyslov, čo vplýva nielen na poznávanie, na emócie, ale aj na dlhodobé zapamätanie.

Uvedené skúmanie prinieslo aj kvantitatívne ukazovatele. Uvedieme ich v podobe percentuálneho hodnotenia úspešnosti jednotlivých oblastí didaktických testov. Do pozornosti si dovolíme dat' fakt, že v každej jednej položke, ktoré boli $\mathrm{v}$ testoch štruktúrované tak, aby vychádzali taxonómie ciel'ov, vyšli respondenti experimentálnej skupiny ako tí úspešnejší. Preto uvedieme len percentuálne vyčíslenie hodnôt, ktoré znamenajú rozdiel medzi dvoma skupinami, teda o kol'ko percent bola experimentálna skupina v odpovediach úspešnejšia, než kontrolná.

\section{A Cvičenia na odkrývanie vzt'ahov}

1. Pre koho je les domovom?

$1,96 \%$

2. Uved'te aspoň tri stromy

$39,99 \%$

3. Ktoré zo slov do vety nepatrí?

$25,81 \%$

V druhej položke mali uviest' stromy, ktoré majú listy. V experimentálnej skupine boli aj menej známe listnaté stromy, ktoré sa v kontrolnej skupine neobjavili. V tretej položke išlo o vetu: V lesnom spoločenstve žijú rastliny, l'udia, stromy a domy.

\section{B Cvičenia na odhal'ovanie a riešenie problémov}

4. Prečo sa les volá spoločenstvo?

5. Prečo si lesy zaslúžia osobitú pozornost??

6. Čo by sa stalo keby...

7. Prečo je dôležitý zber papiera?

V šiestej položke išlo o vyjadrenie, čo by sa stalo, keby v lese nerástli stromy, keby sme stromu nalomili konár, keby sme ho celý zlomili.

\section{Cvičenia na pozorovanie a porovnávanie}

8. Na základe obrázkov určte

9. Z predstavy popíšte les

V položke 8 , kde mali vyčítat' z obrázka, išlo o to, aby sa vyjadrili, čím sa od seba odlišujú stromy podl'a ich vonkajšej podoby. V deviatej položke mali 
$\mathrm{z}$ predstavy popísat' les $\mathrm{v}$ zime a porovnat' ho s lesom v lete. V poslednej položke mali porovnat prácu lesného pracovníka, pol'ovníka vlese a robotníka $v$ drevospracujúcom priemysle.

Okrem toho, že didaktické testy z hl'adiska správnosti odpovedí, ktoré podnecovali logické myslenie žiakov vyšli úspešnejšie v experimentálnej skupine, musíme konštatovat', že aj z hl'adiska kvalitatívnych jazykových ukazovatel'ov boli tieto odpovede kvalitnejšie. Uvedieme niektoré argumenty. Boli to: Zrozumitelnejšie odpovede, ktoré boli výsledkom hlbšieho zamyslenia. Žiaci použivali skôr rozvité vety ktoré boli dôkazom logickej úvahy. Vodpovediach využili aj argumenty založené na vlastnej skúsenosti. Dokázali dôslednejšie a konkrétnejšie popísat' svoje predstavy. Vo svojich výpovediach prejavovali svoju citovú zaangažovanost'. Z výpovedi bola čitatelná aj hodnotová orientácia žiakov.

Odpovede žiakov, ktorí neabsolvovali vyučovanie s lesným pedagógom: Niektoré z odpovedi boli nezrozumitelné, nedávali logické vysvetlenie. Vo väčšej miere použivali skôr jednoduché vety, až jednoslovné odpovede. Niektorí žiaci neodpovedali na niektoré otázky. Z odpovedi, ktoré uviedli $k$ tretej oblasti, $k$ predstavám, išlo vo viacerých prípadoch o nepresné popísanie predstavy, skôr len čiastočné body. Z odpovedi bolo zrejmé, že žiaci vychádzali v nich len zteoretických vedomostí. V̌̌iadnej z odpovedí sme nepostrehli, že by sa niekto vyjadril cez subjektívne preživanie.

\section{Záverečné odporúčania}

Samozrejme, že uvedené výsledky v tomto prípade sú nám len signálom $\mathrm{k}$ tomu, či má význam sa v našich školských podmienkach zaoberat' lesnou pedagogikou a jej legálnym vstupom do škôl. Ak sa rozhodneme pre tento krok, rozhodne by si táto problematika zaslúžila rozsiahlejší a hlbší výskum, možno aj nasmerovaný $\mathrm{k}$ jej uplatneniu smerom k predprimárnemu vzdelávaniu, prípadne k jej využívaniu v školských zariadeniach, pretože v nej vidíme vel'ký potenciál aj vo výchove.

Výskumné dáta môžu byt' aj inšpiráciou pre pedagogickú prax. Odporúčali by sme pedagógom, aby sa informovali o možnostiach lesnej pedagogiky vo vzdelávacom procese, aby sa nakontaktovali na najbližšieho lesného pedagóga a dohodli si možnosti výučby. Ak sa učitelia rozhodnú pre výučbu lesným pedagógom, je vhodné to zarad'ovat' aspoň 6-krát ročne. Je vhodné začat' s lesnou pedagogikou už od prvého ročníka na základnej škole, prípadne ju odporúčame aj v predprimárnom vzdelávaní. Napokon, aj naše výskumné zistenia ukázali, že má zmysel nechat' určité témy Školského vzdelávacieho programu zo vzdelávacej oblasti Človek a príroda nechat' odučit' lesným pedagógom. Len pripomenieme, že tieto vyučovacie hodiny môžeme prepojit' aj s iným vyučovacím predmetom, kvôli jej časovej náročnosti. Školy, ktoré majú skúsenosti s lesnou pedagogikou odporúčajú, aby súčast'ou tejto výučby boli aj rodičia.

\section{Záver}

Les ponúka priestor pre výchovu a vzdelávanie, môže byt' teda pre deti/žiakov predmetom skúmania. Súčasná denná realita, v ktorej prevládajú moderné technológie, do istej miery spôsobuje priepast' medzi človekom 
a prírodou. V dennej komunikácii s det'mi treba však vychádzat' z dôležitého predpokladu, že diet'a predškolského a mladšieho školského veku je vd'ačný pozorovatel' a výskumník prírody. Do jej zákonitostí prenikne iba prostredníctvom dospelého, ktorý ho bude trpezlivo ňou sprevádzat', nie poučovat', upozorňovat' a napomínat'. Prvé kontakty s lesným prostredím môžu vyvolávat' u diet'at'a okrem množstva otáznikov a túžby objavovat', aj negatívne emócie. Ked'že deti prichádzajú z rôznych rodinných prostredí a aj nie všetci učitelia majú rovnaké vedomosti a skúsenosti s lesným prostredím, je vel'kou devízou, že tieto prírodovedné témy z oblastí Človek a spoločnost', Človek a príroda, Človek a svet práce môžu uchopit' lesní pedagógovia, ktorí prostredie lesa a jeho fungovanie celého lesného spoločenstva dôverne poznajú. Dokážu ho det'om sprostredkovat' tak, aby diet'a chcelo objavovat' les, chcelo o ňom vel'a vediet', zatúžilo sa doň vrátit' a dokázalo ho aj chránit'.

\section{Bibliographic references}

KOLLAROVA, D. - MARUSAKOVA, L. 2015. Lesna pedagogika v predprimarnom vzdelavani. In. Predskolska vychova, roc. 25., 2014/2015, c. 3. s. 3 - 8. ISSN 0032-7220.

KUDELOVA, M. 2016. 87 s. 2016. Lesna pedagogika v primarnom vzdelavani /Diplomova praca/. Skolitelka: KOLLAROVA, D. Nitra : PF $\mathrm{UKF}, 87 \mathrm{~s}$.

LOYOVA, D et. al. 2018. Lesna pedagogika : studijna prirucka. Zvolen : Narodne lesnicke centrum. 2018 (t. c. v recenznom konani).

MARUSAKOVA, L. et. al., 2010. Lesna pedagogika ako sucast environmentalnej vychovy na Slovensku - Koncepcia rozvoja. Zvolen : NLC, 2010. 65 s. ISBN 978-80-8093-126-1.

RENZ-POLSTER, H. - HUTHER, G. 2013. Wie Kinder heute wasche. 265 s. ISBN 340-78-59-53-8. Available online: www.Wie-Kinder-heute-wachenEntwicklungsraum-ebook.com

Available online: www.lesnapedagogika.sk

Available online: www.lesy.cz

Available online: www.statpedu.sk

doc. PaedDr. Dana Kollárová, PhD.

Katedra pedagogiky

Department of education

Faculty of Education

Cotantine the Phiosopher University

Drážovská cesta 4, 94974 Nitra

Slovakia

dkollarova@ukf.sk 